\title{
Pengungkapan Corporate Social Responsibility Terhadap Nilai Perusahaan Dengan Profitabilitas Sebagai Variabel Moderating
}

\author{
Ida Nuryana, dan Elisabet Bhebhe
}

Fakultas Ekonomika dan Bisnis Universitas Kanjuruhan Malang

Jl. S. Supriyadi No. 48 Malang, 65148 Indonesia

\section{Info Article}

Keywords:

Corporate social responsibility disclosure; Firm value; and Profitability

ISSN (print) : 2598-7763

ISSN (online): 2598-7771

$\triangle$ Corresponding Author: Ida Nuryana:

Tel. /Fax. +62 821-3263-5999

E-mail: Idanuryana1@gmail.com

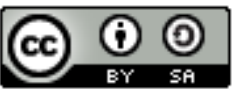

\begin{abstract}
Abtract
The purpose of this study was to determine the effect of corporate social responsibility disclosure on firm value with profitability as a moderating variable. The sample used in the study was 90 observations from the basic industrial and chemical manufacturing companies listed on the Indonesia Stock Exchange for the period 2015-2017. The data in the study came from the secondary data obtained through technical documentation. The data of this study was to qualify the classical assumption and moderated regression analysis (MRA) test requirements. the results of the analysis show that the corporate social responsibility disclosure does not affect the company value and profitability can moderate the relationship between corporate social responsibility disclosure and company value.

Citation: Nuryana, Ida dan Bhebhe, Elisabet. (2019). Pengungkapan Corporate Social Responsibility Terhadap Nilai Perusahaan Dengan Profitabilitas Sebagai Variabel Moderating. Accounting and Financial Review, 2 (2)

Abstraks

Tujuan dari penelitian ini adalah untuk mengetahui pengaruh pengungkapan corporate social responsibility (CSR) terhadap nilai perusahaan dengan profitabilitas sebagai variabel moderating. Sampel yang dipakai dalam penelitian adalah 90 data dari perusahaan manufaktur sektor industri dasar dan kimia yang terdaftar di Bursa Efek Indonesia periode 2015-2017. Data dalam penelitian ini adalah data sekunder yang diperoleh melalui teknik dokumentasi. Data penelitian ini sudah memenuhi syarat uji asumsi klasik dan uji moderated regresion analysis (MRA). Hasil analisis menujukan bahwa pengungkapan CSR tidak berpengaruh terhadap nilai perusahaan dan profitabilitas mampu memoderating hubungan antara pengungkapan CSR dengan nilai perusahaan.
\end{abstract}

JEL Classification: G3, M1

DOI: https://doi.org/10.26905/afr.v2i2.3261

\section{PENDAHULUAN}

Di era globalisasi sekarang ini, perkembangan di dunia usaha semakin pesat dan perusahaan tidak hanya dituntut untuk mengejar keuntungan ekonomi semata. Namun, perusa-haan juga harus memikirkan bagaimana cara memberikan kontribusi kepada para stakeholder. Salah satu cara perusahaan memberikan kontribusi kepada para stakeholder adalah dengan menerapkan program kepedulian kepada masyarakat disekitarnya yang disebut tanggung jawab sosial perusahaan atau corporate social respons-ibility (CSR). CSR ini merupakan salah satu upaya untuk menciptakan keberlangsungan usaha dan memelihara keseimbangan antara mengejar keuntungan ekonomis, fungsi-fungsi sosial dan pemeliharaan lingkungan hidup (triple bottom line) (Effendi, 2016:163).

Manajemen dalam pengelolaan perusahaan berorientasi pada $3 \mathrm{P}$, yaitu: profit, people dan planet (Parmar, Keevil, \& Wicks, 2019). Perusahaan tidak hanya beroreintasi pada profit saja, namun akan memikirkan lingkungan. Perusahaan 
yang tidak memiliki kepedulian sosial akan banyak menemui berbagai kendala seperti seringnya masyarakat sekitar berunjuk rasa, bahkan ada perusahaan yang terpaksa ditutup oleh pihak yang berwenang (Effendi, 2016:163). Pelaku bisnis dituntut bukan hanya berorientasi mengoptimalkan laba, tetapi juga mampu memberikan kontribusi positif terhadap lingkungan sekitar. Perusahaan dituntut memiliki tanggungjawab untuk kerusakan lingkungan yang diakibatkan oleh aktivitas operasional perusahaan. Image perusahaan akan cenderung lebih tinggi pada perusahaan yang tidak hanya berorintasi pada profit, namun juga people dan planets.

Perusahaan akan mampu survive jika perusahaan beroperasi sesuai dengan tata nilai dan sistem nilai yang berlaku di masyarakat. Perusahaan harus mengetahui dan mengikuti sistem nilai yang berlaku. Sehingga perusahaan tidak bisa dilepaskan dari sistem nilai yang ada di masyarakat. Perusahaan harus memperhatikan lingkungan (Pondrinal, 2019)

Corporate social responsibility bukan hanya bersifat sukarela, melainkan bersifat wajib dilakukan perusahaan. Hal tersebut diataur dalam Undang-undang PT Nomor 40 Tahun 2007 pasal 47, menyebutkan: (1) perseroan yang menjalankan kegiatan usahanya dibidang dan/atau berkaitan dengan sumber daya alam wajib melaksanakan tanggung jawab sosial dan lingkungan. (2) Tanggungjawab sosial dan lingkungan sebagaimana dimaksudkan pada ayat satu merupakan kewajiban yang dianggarkan dan diperhitungkan sebagai biaya perseroan yang pelaksanaannya dilakukan dengan memperhatikan kepatutan dan kewajaran. (3) Peseroan yang tidak melaksanakan kewajiban sebagaimana di-maksudkan pada ayat satu dikenai sanksi sesuai ketentuan peraturan perundang-undangan (UU PT No. 40, 2007).

Berbagai penelitian yang menjelaskan pengaruh CSR terhadap nilai perusahaan diantaranya Rizaldi (2015), Agung (2018), Elia (2018), dan Sarwendah, dkk (2017), dimana hasil penelitian menunjukkan CSR berpengaruh terhadap nilai perushaan. Berbeda dengan penelitian yang dilakukan Irwansyah, at al. (2017), Setiangingrum (2015), Saedah (2015), Frandy (2017), dan Rokhmat, dkk (2015) dimana CSR tidak berpengaruh terhadap nilai perusahaan.

Berbagai penelitian yang menggunakan profitabilitas sebagai variabel moderating hubungan antara CSR dan nilai perusahaan juga menunjukan hasil yang beragam. Irwansyah at al.
(2017), Saedah (2015), Frandy (2017), dan Rokhmat, dkk (2015) membuktikan bahwa profitabilitas mampu memoderasi hubungan antara CSR dan nilai perusahaan. sedangkan Rizaldi (2015), Agung (2018), Elia (2018), dan Sarwendah, dkk (2017) profitabilitas tidak mampu memoderasi hubungan antara CSR dan nilai perusahaan.

Berdasarkan temuan penelitian terkait dengan CSR dan nilai perusahaan menunjukkan hasil yang belum konsisten. Penelitian ini bertujuan 1) untuk mengetahui pengaruh pengungkapan CSR terhadap nilai perusahaan, 2) untuk mengetahui apakah profitabilitas mampu memoderasi CSR terhadap nilai perusahaan.

\section{PENGEMBANGAN HIPOTESIS}

Pengungkapan informasi CSR dalam laporan tahunan diharapkan dapat menjadi nilai tambah yang nantinya akan menambah kepercayaan para investor dan juga untuk memperoleh legitimasi dari masyarakat, bahwa perusahaan tesebut akan terus berkembang dan berkelanjutan (sustainable) serta berkaitan erat dengan pencitraan yang ingin ditunjukkan oleh perusahaan di mata masyarakat atau konsumen (Rizaldi, 2015).

Penelitian ini mengacu pada penelitian Alice (2014), Irwansyah, at al. (2017), Frandy (2017), dan Sarwendah, dkk (2017) yang meneliti pengaruh CSR terhadap nilai perusahaan dengan profitabilitas sebagai variabel moderating.

$\mathrm{H}_{1}$ : Pengungkapan Corporate Social Responsibility berpengaruh positif terhadap nilai perusahaan.

Tingkat profitabilitas yang semakin besar menunjukkan perusahaan mampu mendapatkan laba yang semakin besar, sehingga perusahaan mampu untuk meningkatkan aktivitas tanggung jawab sosial, serta mengungkapkan tanggung jawab sosialnya dalam laporan tahunan dengan lebih luas. Temuan penelitian Frandy (2017) bahwa profitabilitas sebagai variabel moderasi mampu memoderasi hubungan CSR dengan signifikan terhadap nilai perusahaan.

$\mathrm{H}_{2}$ : Profitabilitas berpengaruh positif sebagai variabel moderating dalam hubungan antara pengungkapan CSR dengan nilai perusahaan.

\section{DATA DAN METODE}

Penelitian ini dilakukan pada perusahaan manufaktur sektor industri dasar dan kimia yang terdaftar di BEI. Periode pengamatan tahun 2015- 


\section{Pengungkapan Corporate Social Responsibility Terhadap Nilai Perusahaan Dengan Profitabilitas Sebagai Variabel Moderating \\ Ida Nuryana, dan Elisabet Bhebhe}

2017. Data yang digunakan berasal dari laporan keuangan (financial report) perusahaan yang diperoleh dari Bursa Efek Indonesia melalui akses website www.idx.co.id.

Populasi dalam penelitian ini berjumlah 70 perusahaan. Metode pemilihan sampel yang digunakan dalam penelitian ini adalah purposive sampling. Jumlah perusahaan yang menjadi sampel sebanyak 30 perusahaan.

Variabel nilai perusahaan diukur dengan menggunakan Tobin's Q, Salah satu versi Tobin's $\mathrm{Q}$ yang dimodifikasi dan disederhanakan oleh Klappe dan Love dalam (Hidayah, 2018).

$$
\mathrm{Q}=\frac{\{(\mathrm{CPX} \text { Jumlah Saham yang Beredar })+(\mathrm{TL}+1)\}-C A}{\mathrm{TA}}
$$

Keterangan $: \mathrm{Q}=$ Nilai Perusahaan, $\mathrm{CP}=$ Closing Price, $\mathrm{TL}=$ Total Liabilities, $\mathrm{I}=$ Inventory, $\mathrm{CA}=$ Current Assets, $\mathrm{TA}=$ Total Assets

Variabel Pengungkapan CSR yang dilakukan oleh perusahaan dalam laporan tahunan dapat diukur dengan cara menghitung indeks pengungkapan CSR. Rumus penghitungan Corporate Social Responsibility Index (CSRI) sebagai berikut:

$$
\mathrm{CSRIj}=\frac{\Sigma \mathrm{Xij}}{\mathrm{Nj}}
$$

Keterangan: $\mathrm{CSRIj}=$ Pengungkapan Corporate Social Responsibility Index perusahaan j, $\Sigma$ xij = Jumlah item yang sesungguhnya diungkapkan oleh perusahaan (dummy variable)

Variabel profitabilitas diukur dengan menggunakan ROE. Dimana perhitungan ROE sebagai berikut:

$$
\text { ROE }=\frac{\text { Laba bersih setelah pajak }}{\text { Total Equitas }}
$$

Teknik analisis data yang digunakan dalam penelitian ini adalah analisis deskriptif dan analisis statistik infernsial. Analisis statistik inferensial terdiri dari uji asumsi klasik, uji moderated regression analysis (MRA) dan uji hipotesis. Analisis MRA digunakan untuk menguji apakah variabel profitabilitas dapat mempengaruhi hubungan antara pengungkapan CSR dengan nilai perusahaan, maka didapati persamaan regresi sebagai berikut:

$$
\mathrm{NP}=\alpha+\mathrm{b} 1 \mathrm{CSR}+\mathrm{b} 2 \mathrm{CSR} * \mathrm{PRF}+\mathrm{e}
$$

Keterangan: $\mathrm{NP}=$ Nilai Perusahaan, $\alpha=$ Konstanta, $\beta=$ Koe-fisien Regresi, CSR= Corporate Social Responsibility, $\mathrm{PRF}=$ Profitabilitas, $\mathrm{CSR} * \mathrm{PRF}=$ Interaksi antara pengungkapan CSR dengan profitabilitas dan $\mathrm{e}=$ error

\section{HASIL}

\section{Moderated Regresion Analysis (MRA)}

Analisis regresi yang digunakan dalam penelitian ini adalah regresi linier berganda dan Moderated Regression Analysis untuk mengetahui gambaran mengenai pengaruh kinerja keuangan terhadap nilai perusahaan dengan kebijakan dividen sebagai pemoderasi secara parsial. Hasil analisis regresi disajikan pada tabel 1.

Tabel 1 Hasil Analisis Regresi

\begin{tabular}{lll}
\hline \multicolumn{1}{c}{ Variabel } & \multicolumn{1}{c}{$\begin{array}{c}\text { Standardized } \\
\text { Coefficients Beta }\end{array}$} & Sig. \\
\hline Konstanta & 5,389 & 0,077 \\
CSR & $-0,147$ & 0,358 \\
CSR PProfitabitas & 0,426 & 0,009 \\
$\mathrm{R}^{2}$ & 0,029 & \\
\hline
\end{tabular}

Berdasarkan hasil analisis regresi pada tabel 1 menunjukkan bahwa CSR tidak berpengaruh terhadap nilai perusahaan. Persamaan regresi dari hasil analisis tersebut dapat dituliskan sebagai berikut:

$$
\mathrm{NP}=5,389-0,147 \mathrm{CSR}+0,426 \mathrm{CSR} * \mathrm{PRF}
$$

Berdasarkan persamaan moderated regression analysis (MRA) di atas, CSR berpengaruh negatif. Sedangkan Nilai koefisien regresi CSR*PRF bertanda positif 0,426 yang menunjukan bahwa variabel profitabilitas yang diproksikan dengan ROE berhubungan positif terhadap hubungan antara pengungkapan CSR dengan nilai perusahaan.

Setelah dilakukan moderated regression analysis (MRA) atau analisis regresi moderasian, selanjutnya akan melakukan pengujian hipotesis. Pengujian hipotesis bertujuan untuk menguji apakah pengungkapan CSR berpengaruh secara parsial terhadap nilai perusahaan dan apakah profitabilitas memoderasi variabel independen yaitu pengungkapan CSR secara parsial terhadap variabel dependen yaitu nilai perusahaan. Selanjutnya hasil analisis disajikan pada gambar 1 .

Hasil analisis disajikan pada gambar 1 . Bersarkan hasil analisis menunjukkan bahwa pengungkapan CSR tidak berpengaruh terhadap nilai perusahaan. Maka hipotesis pertama $\left(\mathrm{H}_{1}\right)$ yang menyatakan bahwa pengungkapan CSR berpengaruh terhadap nilai perusahaan ditolak. Sedangkan Nilai signifikansi variabel moderating profitabilitas sebesar 0,009 . Hal ini menunjukan bahwa profitabilitas mampu memoderasi hubungan antara CSR dengan nilai perusahaan. Maka 
hipotesis kedua $\left(\mathrm{H}_{2}\right)$ yang mengatakan bahwa profitabilitas memoderasi hubungan antara pengungkapan CSR dengan nilai perusahaan diterima

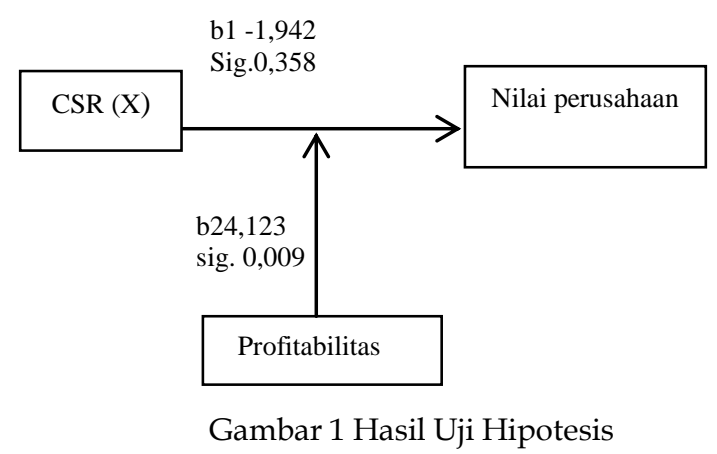

\section{PEMBAHASAN}

Pengungkapan Corporate Social Responsibility (CSR) Terhadap Nilai Perusahaan

Hasil penelitian menunjukkan pengungkapan CSR tidak berpengaruh terhadap nilai perusahaan. Hal ini mengindikasikan bahwa investor informasi pengungkapan CSR belum menjadi pertimbangan penting bagi investor. Pengungkapan CSR yang tinggi atau rendah yang dilakukan oleh perusahaan, tidak menjadi informasi yang penting bagi investor. Pengungkapan CSR bagi investor tidak akan berdampak langsung pada nilai investasi dan expected return dari investasinya.

Investor cendrung membeli dan menjual saham tanpa memperhatikan seberapa besar perhatian perusahaan terhadap lingkungan. Investor lebih memilih saham dengan melihat market economy, faktor keuangan dan berita-berita yang muncul sehingga umumnya cenderung membeli dan menjual saham secara harian. Sedangkan pengaruh CSR merupakan strategi yang tidak dapat dirasakan dalam jangka pendek, melainkan strategi jangka panjang perusahaan dalam upaya untuk menjaga keberlangsungan hidup perusahaan. Sehingga pengungkapan CSR hanya akan menimbulkan biaya tambahan bagi perusahaan.

Hasil penelitian ini sejalan dengan temuan penelitian Wibowo dan Faradiza (2014), Nurhayati, dkk. (2019), Suryati dkk. (2019) dimana pengungkapan CSR tidak berpengaruh terhadap nilai perusahaan. Namun penelitian ini tidak sejalan dengan temuan penelitian Vollono (2010).

Profitabilitas sebagai Variabel Moderating dalam hubungan antara Corporate Social Responsibility dengan Nilai Perusahaan
Profitabilitas dapat memoderating hubungan antara pengungkapan CSR dengan nilai perusahaan. Profitabilitas merupakan faktor yang menjadikan manajemen lebih bebas dan fleksibel dalam mengungkapkan CSR kepada shareholder dan stakeholder. Profitabilitas yang semakin tinggi akan membuat manajemen dapat melakukan dan mengungkapkan aktivitas CSR secara lebih luas atau dengan kata lain pengungkapan CSR akan dapat meningkatkan nilai perusahaan pada saat profitabilitas perusahaan tinggi, karena dalam pengungkapan CSR membutuhkan dana, dana tersebut diperoleh dari tingkat keuntungan yang dimiliki oleh perusahaan.

Hasil penelitian ini sejalan dengan penelitian Nurhayati, dkk. (2019). Namun penelitian ini tidak sejalan dengan temuan penelitian Kusuma dan Priantinah (2018).

\section{SIMPULAN DAN SARAN}

Berdasarkan hasil analisi dan pembahasan dapat diambil kesimpulan, bahwa: 1) Corporate social responsibility (CSR) tidak berpengaruh terhadap nilai perusahaan. 2) Profitabilitas secara parsial dapat memoderasi hubungan antara corporate social responsibility (CSR) dengan nilai perusahaan atau dengan kata lain pengungkapan CSR akan dapat meningkatkan nilai perusahaan pada saat profitabilitas perusahaan tinggi, karena dalam pengungkapan CSR membutuhkan dana, dana tersebut diperoleh dari tingkat keutungan yang dimiliki oleh perusahaan.

Untuk peneliti selanjutnya dapat melakukan penelitian dengan menggunakan periode yang lebih lama dimana dapat memperkuat hasil penelitian, perlu mempertimbangkan untuk menambah sampel yang lebih luas dengan maksud agar kesimpulan yang dihasilkan memiliki cakupan yang lebih luas yaitu dengan meneliti pada setiap sektor secara menyeluruh agar hasil dapat digeneralisai, dan menambah beberapa variabel yang bisa dihubungkan dengan nilai perusahaan. Salah satu contohnya adalah kepemilikan manajerial, penerapan good corporate governance (GCG), ukuran perusahaan dan lainlain.

\section{DAFTAR PUSTAKA}

Agung, Anak Ayu Mutya Armika. (2018). Pengaruh Pengungkapan Tanggung Jawab Sosial Pada Nilai Perusahaan Dengan Profitabilitas Sebagai Variabel Pemoderasi. E- 


\section{Pengungkapan Corporate Social Responsibility Terhadap Nilai Perusahaan Dengan Profitabilitas Sebagai Variabel Moderating \\ Ida Nuryana, dan Elisabet Bhebhe}

Jurnal Akuntansi Universitas Udayana, 22 (1): 80-107.

Effendi. (2016). The Good Corporate Governance Teory Dan Implementasi, Edisi 2. Jakarta; Salemba Empat.

Elia, Putu Meilinda Murnita. (2018). Pengaruh Corporate Social Responsibility Terhadap Nilai Perusahaan Dengan Profitabilitas Sebagai Vraiabel Pemoderasi. E-Jurnal Akuntansi Universitas Udayana, 23 (2). : 14701496.

Frandy. (2017). Analisis Pengaruh Corporate Social Responsibility terhadap Nilai Perusahaan dengan Profitabilitas, Kepemilikan Manajemen, dan Ukuran Perusahaan sebagai Variabel Moderasi (Studi Empiris pada Perusahaan Pertambangan yang Terdaftar di Bursa Efek Indonesia Tahun 2012 2016). Skripsi. Fakultas Ekonomi dan Bisnis, Universitas Sam Ratulangi.

Gama, W.S.A., dan Ni Putu Yeni Astiti, Y.P.N., (2019). Pengaruh Corporate Social Responsibility Terhadap Nilai Perusahaan Dengan Profitabilitas Sebagai Variabel Moderasi (Studi Empiris Pada Perusahaan Pertambangan yang Terdaftar di Bursa Efek Indonesia Periode 2014-2016). Forum Manajemen. 17 (2)

Hidayah, E. (2008). Pengaruh Kulitas Pengungkapan Informasi Terhadap Hubungan Antara Penerapan Corporate Governance Dengan Kinerja Di Bursa Efek Jakarta. Jurnal Akuntansi dan Auditing Indonesia. 12 (1).

Irwansyah, Lestari, Y., Kusumawardani, A. And Erdiyanti, J. (2017). Corporate Social Responsibility Disclosure, Leverage, and Firm Value: The Moderating Role Of Profitability. Advances in Economics, Business and Management Research (AEBMR). 35.

Kusuma, W.A. dan Priantinah, D. (2018). Pengaruh Pengungkapan Sustanability Report dan Ukuran Perusahaan Terhadap Nilai Perusahaan Dengan Profitabilitas Sebagai Variabel Pemoderasi Pada Perusahaan Yang Bergabung Di ISSI dan Konvensional Periode 2014-2016. Jurnal Nominal 7 (2).

Nurhayati, I., Poerwati, T., dan Kartika, A., (2019). Dampak Moderasi Profitabilitas dan Leverage Terhadap Pengaruh CSR Pada Nilai Perusahaan Di Indonesia. Prosiding SENDI_U 2019

Parmar, L. B., Keevil, A., and Wicks, C. A., (2019).
People and Profits: The Impact of Corporate Objectives on Employees' Need Satisfaction at Work. Journal of Business Ethics. 154 (1): 13-33

Pondrinal, Muhammad. (2019). Pengaruh Pengungkapan Corporate Social Responsibility (CSR) Terhadap Kinerja Keuangan Di Perusahaan Yang Go Public. Jurnal EKOBISTEK. 8 (1): 51-59 Rizaldi, Aulia. (2015). Pengaruh Corporate Social Responsibility (CSR) Terhadap Nilai Perusahaan Dengan Profitabilitas Sebagai Variabel Moderating. Skripsi Fakultas Ekonomi. Sekolah Tinggi Ilmu Ekonomi Perbans. Surabaya.

Rokhmat, Diana, dan Afifudin. (2015). Pengaruh Corporate Social Responsibility Terhadap Nilai Perusahaan Dengan Profitabilitas Sebagai Variabel Moderating. E-Jurnal Akuntansi Universitas Islam Malang. 06 (06).

Saedah, Zuhro. (2015). Pengaruh CSR Terhadap Nilai Perusahaan Dengan Profitabilitas Sebagai Variabel Moderating (Studi Pada Perusahaan Manufaktur Di BEI periode Tahun 2011-2013). Skripsi Fakultas Ekonomi. Universitas Muhmmadiyah Surakarta.

Sarwendah, Anita, dan Endang. (2017). Pengaruh Corporate Social Responsibility Terhadap Nilai Perusahaan Dengan Profitabilitas Sebagai Variabel Moderating. Skripsi Fakultas Ekonomi. Universitas Islam Batik. Surakarta.

Setiangingrum, Wahyuning Ambar. (2015). Pengaruh Corporate Social Responsibility Terhadap Nilai Perusahaan Dengan Profitabilitas Sebagai Variabel Moderasi (studi pada perusahaan manufaktur yang terdaftar di BEI Periode 2011-2013). Skripsi Fakultas Ekonomi. Universitas Negeri. Semarang.

Sugiyono. 2013. Metode Penelitian Kuantitatif, Kualitatif dan RED. Bandung: Alfabeta.

Undang-undang PT Nomor 40 Tahun 2007 pasal 47 Tentang Perseroan Terbatas.

Wibowo dan Faradiza. (2014). Dampak Pengungkapan Sustainability Report Terhadap Kinerja Keuangan dan Pasar Perusahaan. Makalah disampaikan pada Simposium Nasional Akuntansi, 17

Vollono, R., (2010). Doing Well By Doing Good: The Empirical Relationship Between Corporate Social Responsibility and Financial Performance. Thesis Faculty of the Graduate School of Arts and Sciences of Georgetown 